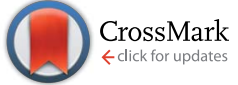

Cite this: RSC Adv., 2016, 6, 97216

Received 12th August 2016 Accepted 4th October 2016

DOI: $10.1039 / c 6 r a 20409 k$

www.rsc.org/advances

\section{Novel $\beta$-galactosidase nanobiocatalyst systems for application in the synthesis of bioactive galactosides $\uparrow$}

\author{
Katarina Banjanac, ${ }^{a}$ Milica Carević, ${ }^{\star a}$ Marija Ćorović, ${ }^{a}$ Ana Milivojević, ${ }^{a}$ \\ Nevena Prlainović, ${ }^{b}$ Aleksandar Marinkovićc and Dejan Bezbradica ${ }^{a}$
}

In this study, unmodified, amino modified and cyanuric chloride functionalized amino modified nonporous fumed nano-silica particles (FNS, AFNS and CCAFNS, respectively) were used for the development of efficient nanobiocatalysts for application in the biosynthesis of bioactive galactosides, galactooligosaccharides (GOS). Hence, in an attempt to elucidate the mechanism of immobilization, based on available enzyme conformation, the effects of immobilization parameters (initial enzyme concentration, immobilization time and $\mathrm{pH}$ ) were analyzed. Among all three used nano-sized supports, the one with amino groups (AFNS) exhibited the best $\beta$-galactosidase binding capacity of $220 \mathrm{mg} \mathrm{g}^{-1}$ support with the efficiency of $\sim 90 \%$ at $\mathrm{pH} 4.5$ and immobilization time $3 \mathrm{~h}$. The highest hydrolytic activity of $\sim 2200 \mathrm{IU} \mathrm{g}^{-1}$ was achieved, which is far higher than previously reported. Meanwhile, $\beta$-galactosidases covalently immobilized on CCAFNS and adsorbed on FNS nanoparticles were found to have similar trends with respect to immobilization efficiency $(58-71 \%)$ and hydrolytic activity $\left(\sim 600 \quad \mathrm{IU} \mathrm{g}^{-1}\right)$. Furthermore, thermal stability at $60{ }^{\circ} \mathrm{C}$ was increased by $\beta$-galactosidases immobilized on AFNS and CCAFNS (4 and 1.4-fold, respectively) due to the protective effect of interactions formed between enzyme molecules and the surfaces of nanoparticles. Since $\beta$-galactosidase immobilized on AFNS was the nanobiocatalyst with the highest activity and stability, it was applied in GOS production. With AFNS$\beta$-galactosidase GOS production of $90 \mathrm{~g} \mathrm{~L}^{-1} \mathrm{~h}^{-1}$ was achieved as compared to $30 \mathrm{~g} \mathrm{~L}^{-1} \mathrm{~h}^{-1}$ by free $\beta$ galactosidase, meaning that AFNS enhanced the selectivity of $\beta$-galactosidase for transgalactosylation, which is a crucial advantage for its application in GOS production.

\section{Introduction}

$\beta$-Galactosidase or $\beta$-D-galactoside galactohydrolase (E.C.3.2.1.23) is a ubiquitous enzyme that catalyzes the cleavage of terminal $\beta$ glycosidic bonds in various types of galactosides. Its primary biological function is associated with lactose hydrolysis to its constituents (glucose and galactose), hence major fields of $\beta$ galactosidase applications include processing of lactosecontaining products, enabling the improvement of digestibility and technological and sensorial characteristics of sweetened, condensed and frozen dairy products, as well as solving the considerable problem of whey utilization and appropriate disposal. ${ }^{\mathbf{1 , 2}}$ Nevertheless, great attention recently has been drawn

${ }^{a}$ Department of Biochemical Engineering and Biotechnology, Faculty of Technology and Metallurgy, University of Belgrade, Karnegijeva 4, 11000 Belgrade, Serbia. E-mail: mcarevic@tmf.bg.ac.rs

${ }^{b}$ Department of Organic Chemistry, Innovation Center of Faculty of Technology and Metallurgy, University of Belgrade, Karnegijeva 4, 11000 Belgrade, Serbia

'Department of Organic Chemistry, Faculty of Technology and Metallurgy, University of Belgrade, Karnegijeva 4, 11000 Belgrade, Serbia

$\dagger$ Electronic supplementary information (ESI) available. See DOI: $10.1039 / \mathrm{c} 6 \mathrm{ra} 20409 \mathrm{k}$ to prospective use of this enzyme to catalyze the kinetically controlled reaction of transgalactosylation, where a galactose moiety is transferred to an alternative acceptor, such as a sugar, alcohol, or some aromatic glucoside, under appropriate conditions (high lactose content, high temperatures, low water activity). ${ }^{3,4}$ This feature has paved the way for production of myriad of physiologically active galactosides. ${ }^{5-10}$ Among the others, galacto-oligosaccharides (GOS) earned the prominent interest owing to their exceptional features. GOS represent a diverse group of carbohydrates built of several galactose and usually one terminal glucose unit, with varying molecular weight, structure, and corresponding properties, depending on enzyme origin and employed reaction conditions. ${ }^{11,12}$ They are regarded as non-digestible compounds with high prebiotic potential, since they provide selective proliferation of intestinal microbiota beneficial bacteria while simultaneously enabling promotion of their activity. ${ }^{\mathbf{1 3 , 1 4}}$ Accordingly, several positive effects on human well-being can be ascribed to their consumption, such as improvement of lactose digestion and mineral absorption, reduction of serum cholesterol level, inhibition of intestinal pathogen growth, diminishing the risk of cancer, and enhancement of the host's immune system. ${ }^{\mathbf{1 3}, \mathbf{1 4}}$ Moreover, they proved to 
be components of choice for infant milk formulas, dairy products, beverages, and animal feed, in view of excellent thermal and acid stability, low sweetness and caloric value, and notable contribution to taste quality. ${ }^{\mathbf{1 3 , 1 5}}$

Even though GOS production is well-established, and soluble enzymes are most frequently used, the instability of the $\beta$-galactosidase may impose as a major drawback, limiting the potential of GOS synthesis. In terms of overcoming this issue, enzyme immobilization has been proposed as one of the best alternatives. Substantial research efforts have been made in developing an adequate immobilized $\beta$-galactosidase preparation. Different immobilization methods (adsorption, covalent binding, entrapment and cross-linking), and various support materials, including natural ${ }^{\mathbf{1 6 - 1 8}}$ and synthetic polymers ${ }^{\mathbf{1 0 , 1 9 - 2 1}}$ or inorganic materials, ${ }^{22-25}$ have been tested for immobilization of $\beta$-galactosidase. Recently, a great deal of interest was drawn to immobilization of industrially important enzymes onto nanoscale materials for improved catalytic performance. ${ }^{26,27}$ These materials exhibited inherent advantages such as large surface to volume ratio and increased enzyme loading per unit mass of particles, thus exhibiting high surface reaction activity and high catalytic efficiency. ${ }^{2,27}$ It is considered that enzymes bound to nano-sized particles exhibit increased mobility in aqueous solutions, and hence express higher enzymatic activities in comparison to native enzymes. Besides, immobilization of enzymes by nano-sized particles can reduce protein unfolding which might turn out essential for their stability and consequently improve their efficiency.

Diverse nano-sized materials were employed for enzyme immobilization to date,,$^{2,25,28}$ nevertheless the silica based nanoparticles, featuring a uniform particle shape, large surface area, exceptional chemical and thermal stability, a good capability of forming fine suspensions in aqueous solution, as well as biocompatibility and non-toxicity, serve as the optimal choice for food and pharmaceutical purposes. ${ }^{29,30}$ Although silica based nanoparticles demonstrated great accomplishment in the enzyme immobilization, surface modification is usually obligatory to achieve better performance. Over the past years, a few surface modification strategies have been developed, but among them, surface modification of silica nanoparticles with organosilanes (silicon-based chemicals that contain both organic and inorganic reactivity in the same molecule) has proved to be the most effective, since it provides diversity in attached functional groups onto the particle surface..$^{31-33}$ So far, silica based nanoparticles modified with various chemical agents have been used in a multitude of applications that include cell imaging and detection, controlled drug-delivery applications, as well as for biomolecule immobilization. ${ }^{\mathbf{3 4 3}}$ Fumed nano-silica (FNS), known for its highly developed nonporous surface area, that additionally lower mass transfer restrictions, has proved to be very efficient immobilization support, especially after modification with aminofunctional organosilane to introduce an amino groups onto its surface. ${ }^{32}$ The introduction of amino groups onto the FNS surface is an effective mechanism to improve biocompatibility between FNS and enzymes due to the possibility of bond formation (hydrogen bond, electrostatic interaction and week van der Waals forces) between amino, carboxyl, thiol and hydroxyl groups of enzyme molecules and introduced amino groups.

In this study, FNS and its derivatives were applied in immobilization of $\beta$-galactosidase from Aspergillus oryzae. Main goal was to achieve further improvement of high transgalactosylation activity previously obtained in its immobilization on aminosupports, ${ }^{20}$ by using nano-sized particles with same functionality. Furthermore, in a subsequent step the amino modified support (AFNS) was subjected to further functionalization with cyanuric chloride (CC) resulting in modified support (CCAFNS) with reactive aromatic chlorine groups on the surface of the nano-silica particles, which can form covalent bonds with nucleophilic groups (thiol, amino, or even hydroxy) of enzyme side chains and showed enhanced activity and stability in lipase immobilization. ${ }^{32}$ Therefore, in this study immobilization of $\beta$-galactosidase from $A$. oryzae onto FNS, AFNS and CCAFNS particles was optimized with respect to the most important factors and thermal stability of all immobilized derivatives was tested. Finally, the most prospective immobilized preparation was employed in GOS synthesis reaction, in order to compare its transgalactosylation potential as opposed to soluble $\beta$-galactosidase.

\section{Experimental}

\section{Materials}

$\beta$-Galactosidase from $A$. oryzae ( $\geq 8$ units per $\mathrm{mg}$ solid) used in this study was purchased from Sigma Chemical Co (St Louis, USA). Nano-sized fumed silica AEROSIL® 380 (FNS), (purity of 99.8\%, average particle diameter $7 \mathrm{~nm}$, specific surface area $380 \pm 30 \mathrm{~m}^{2}$ $\mathrm{g}^{-1}$, tamped density of $50 \mathrm{~g} \mathrm{~L}^{-1}$, as reported by the manufacturer) was obtained from Evonik Industries (Essen, Germany).

Substances (anhydrous 3-aminopropyltrimethoxylsilane (APTMS), (97\%) and cyanuric chloride (CC), (99\%)) used for modification of FNS were purchased from Fluka Analytical (USA). All the other substances used throughout this study, namely 2-nitrophenyl- $\beta$-D-galactopyranoside ( $o$-NPG), Coomassie Brilliant Blue G-250, bovine serum albumin (BSA) and lactose were obtained from Sigma Chemical Co. Ultra-pure water used as the mobile phase for HPLC analysis was purchased from Thermo Fisher Scientific (Rockford, USA). All other reagents used were of analytical grade, and purchased from Centrohem (Stara Pazova, Serbia).

\section{Modification of nano-silica}

The surface of nonporous, nano-sized, fumed silica particles (FNS) was modified with purpose of obtaining amino modified nano-silica particles (AFNS) and cyanuric chloride functionalized amino modified nano-silica particles (CCAFNS). The detailed procedure used for modification of FNS was described in our previously published study. ${ }^{32}$ Briefly, AFNS was prepared by stirring $300 \mathrm{mg}$ FNS particles with $1.18 \mathrm{~mL}$ of APTMS during $48 \mathrm{~h}$ at $25{ }^{\circ} \mathrm{C}$ under inert atmosphere. In order to obtain cyanuric chloride functionalized amino silica (CCAFNS), $300 \mathrm{mg}$ of AFNS particles was treated with $1.5 \mathrm{~g}$ of CC during $2 \mathrm{~h}$ at $0{ }^{\circ} \mathrm{C}$.

All of these three supports (FNS, AFNS and CCAFNS) were used for immobilization of the $\beta$-galactosidase from A. oryzae. 


\section{$\beta$-Galactosidase immobilization procedure}

According to study reported by Carević et al.,${ }^{20}$ for immobilization of $A$. oryzae $\beta$-galactosidase on macro-sized supports with amino and chloride groups, the temperature of $25{ }^{\circ} \mathrm{C}$ and $\mathrm{pH}$ of 4.5 have been specified as optimal. In this study, these parameters were used as benchmark for immobilization $\beta$-galactosidase on nanoparticles with same functional groups. The four different solutions of $\beta$-galactosidase were prepared by dissolving $2,3,6$, and $9 \mathrm{mg}$ of $\beta$-galactosidase powder in $1 \mathrm{~mL}$ of $0.1 \mathrm{M}$ acetate buffer (pH 4.5). $0.5 \mathrm{~mL}$ of each prepared $\beta$-galactosidase solution was individually mixed with $1 \mathrm{mg}$ of support and placed on continuously stirring within an orbital shaker at a speed of $150 \mathrm{rpm}$ and at temperature of $25{ }^{\circ} \mathrm{C}$. After different periods of time (1, 3 and $5 \mathrm{~h}$ ), the samples were taken out and then centrifuged at $13000 \mathrm{rpm}$ for $1 \mathrm{~min}$. Afterwards, the obtained immobilized enzymes were washed with $1 \mathrm{~mL}$ of immobilization buffer and centrifuged in order to eliminate untied enzymes. The immobilization of $\beta$-galactosidase was separately performed on the all three supports FNS, AFNS and CCAFNS in the just described way.

\section{$\beta$-Galactosidase activity assay}

The hydrolytic activity of the $\beta$-galactosidase was determined using $10 \mathrm{mM} o$-nitrophenol- $\beta$-D-galactopyranoside ( $o$-NPG) in $0.1 \mathrm{M}$ acetate buffer $(\mathrm{pH} 4.5)$ as a substrate. The reaction mixture contains $0.1 \mathrm{~mL}$ free enzyme solution or supernatant and $0.9 \mathrm{~mL}$ substrate, or in the case of immobilized enzyme 1 $\mathrm{mg}$ of immobilized preparation with $2 \mathrm{~mL}$ of substrate under vigorous magnetic stirring. The reaction was allowed to proceed at least 3 minutes, while $o$-nitrophenol $(o$-NP) released in reaction was measured spectrophotometrically on Ultrospec 3300 Pro Amersham Biosciences (Freiburg, Germany) spectrophotometer each 30 seconds at $410 \mathrm{~nm}$. One unit is defined as the amount of the enzyme that catalyzes the liberation of 1 $\mu$ mol $o$-NP per min under the assay conditions. The expressed activity was presented in $\mathrm{IU}^{-1}$ of immobilized enzyme and activity immobilization yield (IYa (\%)) was calculated using equation:

$$
\begin{aligned}
\mathrm{IYp}= & \frac{\text { mass of bound enzyme }}{\text { mass of introduced enzyme into immobilization process }} \\
& \times 100
\end{aligned}
$$

\section{Thermal stability assay}

Thermal stability of free $\beta$-galactosidase and $\beta$-galactosidase immobilized on FNS, AFNS and CCAFNS particles (at offered protein concentration $230 \mathrm{mg} \mathrm{g}^{-1}$ support during $3 \mathrm{~h}$ ) were tested at $60{ }^{\circ} \mathrm{C}$ during $24 \mathrm{~h} .1 \mathrm{mg}$ of immobilized enzyme preparations were measured in reaction microtubes, incubated with $1 \mathrm{~mL}$ of 0.1 $\mathrm{M}$ acetate buffer ( $\mathrm{pH}$ 4.5) and placed in Thermo Scientific (Waltham, USA) thermal shaker at $60{ }^{\circ} \mathrm{C}$. In case of free enzyme, 0.1 $\mathrm{mL}$ free enzyme solution concentration of $6 \mathrm{mg} \mathrm{mL}^{-1}$ was mixed with $0.45 \mathrm{~mL}$ of $0.1 \mathrm{M}$ acetate buffer ( $\mathrm{pH} 4.5$ ) and also placed in thermal shaker at same temperature as immobilized enzyme. After different periods of time, the samples were taken out, mixed with $1 \mathrm{~mL}$ (for immobilized enzyme preparations) or $0.45 \mathrm{~mL}$ (for free enzyme) of $20 \mathrm{mM} o$-nitrophenol- $\beta$-D-galactopyranoside $(o$ NPG) in $0.1 \mathrm{M}$ acetate buffer ( $\mathrm{pH} 4.5)$ and stirred on magnetic stirrer in order to determinate their activity. The obtained thermal stability of free and immobilized enzyme on FNS, AFNS and CCAFNS was presented as relative activity during incubating time.

\section{$\beta$-Galactosidase-catalyzed galacto-oligosaccharides synthesis}

The reaction of galacto-oligosaccharides (GOS) synthesis was performed in flasks $(50 \mathrm{~mL})$ placed on an orbital shaker at 200 $\mathrm{rpm}$ at $50{ }^{\circ} \mathrm{C}$ for $8 \mathrm{~h}$. The reaction mixture was composed of $400 \mathrm{~g}$ $\mathrm{L}^{-1}$ lactose solution in $0.1 \mathrm{M}$ acetate buffer and $100 \mathrm{mg}$ of immobilized enzyme. These reaction conditions were applied since they were found to be optimal in our previous reported study. ${ }^{20}$ In reactions carried out with the soluble enzyme the concentration was adjusted to same $\beta$-galactosidase activity (200 IU measured with $o$-NPG). Samples were taken at different times, and the reaction was stopped by heating samples at $100{ }^{\circ} \mathrm{C}$ for 10 min in order to inactivate the enzyme. Samples were ten-fold diluted with deionized water, centrifuged and then analyzed using HPLC. Simultaneously, control samples (without enzyme) were prepared by exposure to the same temperature treatment, and the product was not detected in them.

$$
\mathrm{IYa}=\frac{\text { expressed activity of immobilized enzyme }}{\text { initial activity of enzyme }- \text { activity in supernatant after immobilization }} \times 100
$$

\section{Protein assay}

Concentration of proteins in enzyme solutions and supernatants was assayed according to procedure of Bradford ${ }^{36}$ using bovine serum albumin as the standard. The amount of bound enzyme was determined indirectly from the difference between the amount of enzyme introduced into the reaction mixture and the amount of enzyme in the supernatant after the immobilization. The protein immobilization yield (IYp (\%)) was calculated using equation:

\section{HPLC analysis}

For quantitative analysis of obtained samples, the Dionex Ultimate 3000 Thermo Scientific (Waltham, USA) HPLC system was used. GOS determination was performed using a carbohydrate column (Hyper REZ XP carbohydrate $\mathrm{Ca}^{2+}, 300 \mathrm{~mm} \times 7.7 \mathrm{~mm}, 8$ $\mu \mathrm{m})$ at $80{ }^{\circ} \mathrm{C}$. Deionized water was used as the mobile phase with an elution rate $0.6 \mathrm{~mL} \mathrm{~min}^{-1}$ during the analysis. Detection was performed by RI detector RefractoMax 520, (ERC, Germany). All data acquisition and processing was done using Chromeleon Software. 


\section{Operational stability assay}

Operational stability of $\beta$-galactosidase immobilized on AFNS (at offered protein concentration $230 \mathrm{mg} \mathrm{g}^{-1}$ during $3 \mathrm{~h}$ ) was tested at $50{ }^{\circ} \mathrm{C}$ by carrying out GOS synthesis. The reaction mixture contained $100 \mathrm{mg}$ of immobilized enzyme and $400 \mathrm{~g} \mathrm{~L}^{-1}$ lactose solution in 0.1 M acetate buffer ( $\mathrm{pH} 4.5$ ). After each cycle the amount of synthetized GOS was determined by using HPLC system. The immobilized enzyme was recovered by centrifugation at $13000 \mathrm{rpm}$ for 3 minutes and reused in further cycles under identical conditions.

All the experiments were run in triplicate, and error bars on the graphics represent the standard deviation of the values obtained.

\section{Results and discussion}

\section{Preparation of functionalized nano-silica particles}

Initially, surface of the nano-sized fumed silica (FNS) is covered with high concentration of inert silanol groups ( $\equiv \mathrm{Si}-\mathrm{OH})$ which represent the main surface sites responsible for FNS interactions with interfacial water, organic reagents and biomolecules. ${ }^{37-39}$ In order to change its intrinsic inorganic properties, FNS surface was altered using commercially available bifunctional coupling agent (APTMS) and cyanuric chloride (CC) in a two-step modification process as illustrated in Scheme 1. As result of chemical reaction between silanol groups and methoxysilyl groups of APTMS, stable and uniform silane network with the terminal primary amino groups was formed on support surface (the first modification step). ${ }^{40}$ The efficiency of modification with APTMS was examined through estimation of the density of introduced amino groups on surface of modified FNS. The large acquired density of amino groups (4.58

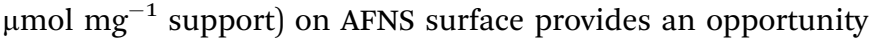
for excessive enzymes attachment. ${ }^{32}$ In the second modification step, the obtained amino modified nano-silica (AFNS) was treated with cyanuric chloride in order to achieve introduction of active chloride groups on AFNS surface. The main goal of second modification step was obtaining nano-sized particles which can be used for covalent immobilization of $\beta$-galactosidase. In addition, the success of conjugation amino and chloride groups onto FNS surface was confirmed by recording FT-IR spectra and performing TGA analysis (ESI Fig. 1 and $2 \dagger$ ).

\section{Immobilization of $\boldsymbol{\beta}$-galactosidase on functionalized silica nanoparticles}

In general, enzyme immobilization onto nano-sized support surface depends on the available surface for enzyme attachment and on the interaction forces between existing functional groups on support surface and the surface of enzyme molecules. ${ }^{41}$ Consequently, for determination of binding capacities for FNS, AFNS and CCAFNS particles, which differ only in functional group present onto their surface, impact of offered protein concentration on protein loading was investigated. Based on the results presented in Fig. 1, it is evident that for all three supports, the protein loading increased continuously with the increase of the offered protein concentration up to $230 \mathrm{mg}$ $\mathrm{g}^{-1}$ support, while the increase of the offered protein concentration beyond this value did not show any improvement in the amount of bound enzyme per $g$ of the support. So, it is estimated that maximum binding capacities for AFNS, CCAFNS and FNS were 220, 130 and $110 \mathrm{mg}$ proteins per $\mathrm{g}$ of support, respectively, which exceeds other nano-sized supports previously used for $\beta$-galactosidase immobilization. ${ }^{\mathbf{4 2 , 4 3}}$ Also, FNS, AFNS and CCAFNS possess a larger available surface area in

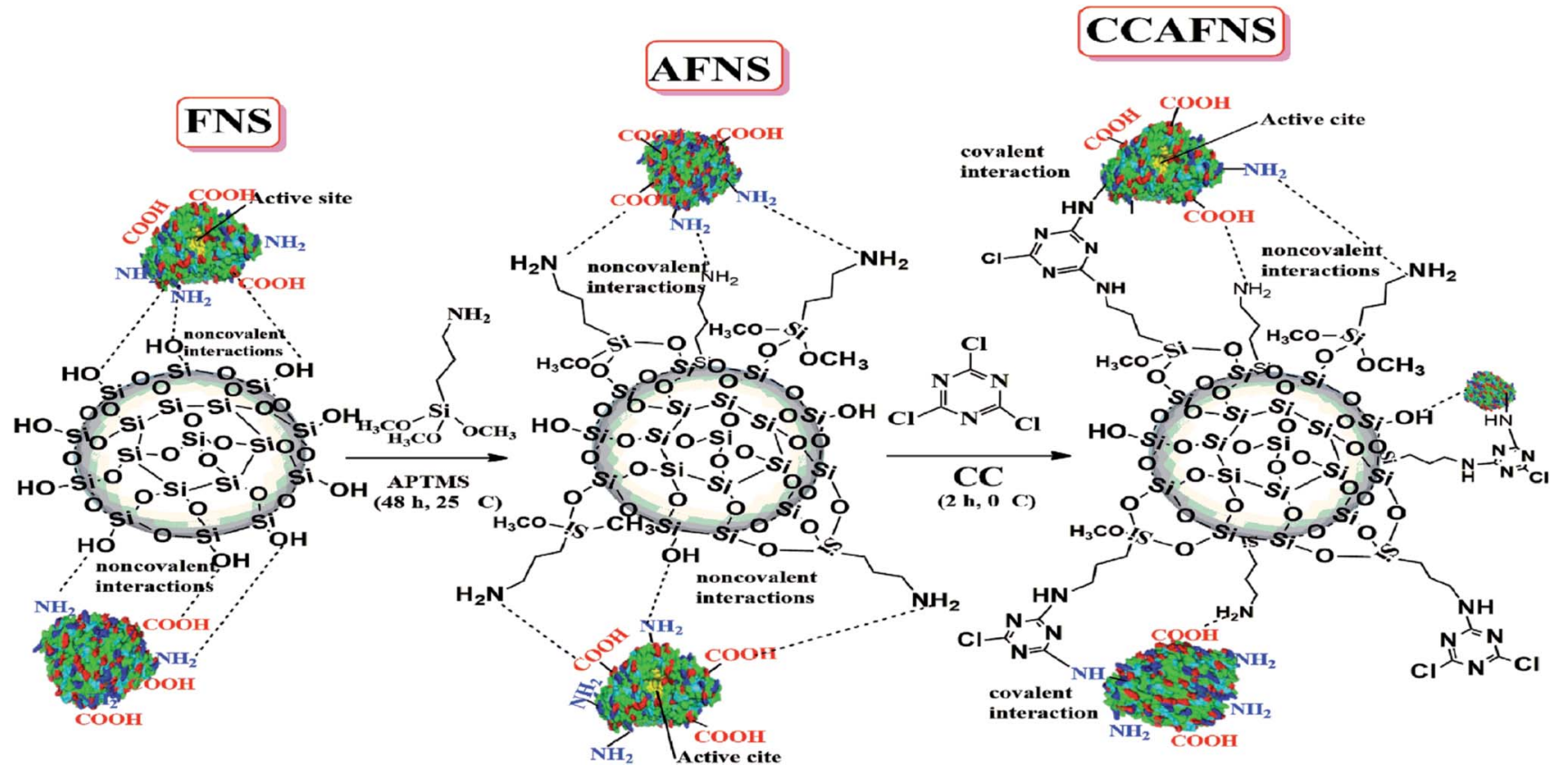

Scheme 1 Schematic presentation of FNS modification process. 


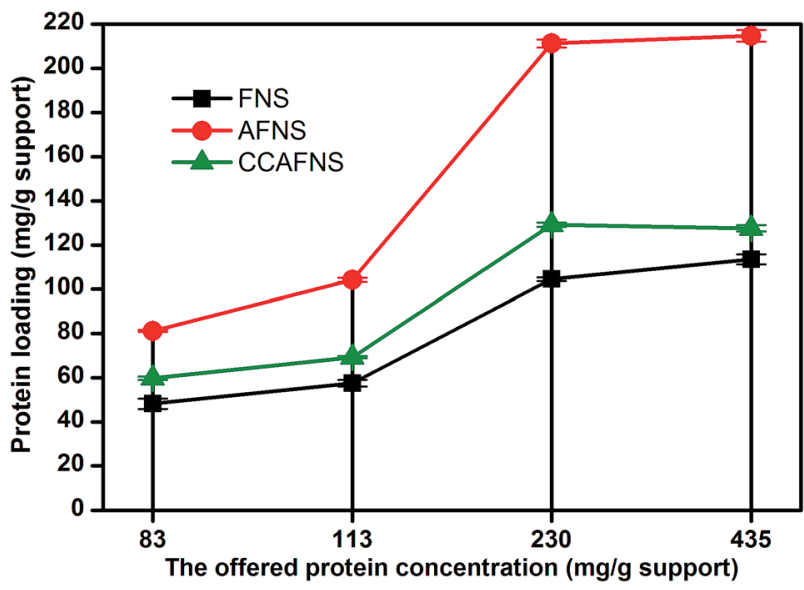

Fig. 1 The impact of the offered protein concentration on protein binding capacity of $\beta$-galactosidase immobilized on FNS, AFNS and CCAFNS. Experimental conditions: $0.1 \mathrm{~mol} \mathrm{~L}^{-1}$ acetate buffer $\mathrm{pH}$ 4.5; immobilization time $3 \mathrm{~h}$; temperature $25^{\circ} \mathrm{C}$.

comparison to commercial macro-sized supports resulting in one order of magnitude higher binding capacities for $\beta$-galactosidase attachment. ${ }^{19,20,44}$

If we analyze the efficiency of $\beta$-galactosidase attachment on FNS, AFNS and CCAFNS particles with respect to the protein immobilization yield (IYp), it can be seen that at the offered protein concentration of $83 \mathrm{mg} \mathrm{g}^{-1}$ support, AFNS bound almost all offered proteins (97.82\%) on its surface (Fig. 2). Even at $230 \mathrm{mg} \mathrm{g}^{-1}$ of offered proteins very high IYp (91\%) indicate that efficient immobilization still happens, but further increase of offered proteins is not justified since steep decrease of IYp occurred. The immobilization on FNS and CCAFNS exhibited similar trends, but with significantly lower maximum IYp of $58.06 \%$ and $71.96 \%$, respectively.

Even though FNS, AFNS and CCAFNS exhibited excellent binding capacity, in order to completely assess the suitability of these supports for $\beta$-galactosidase immobilization, the impact

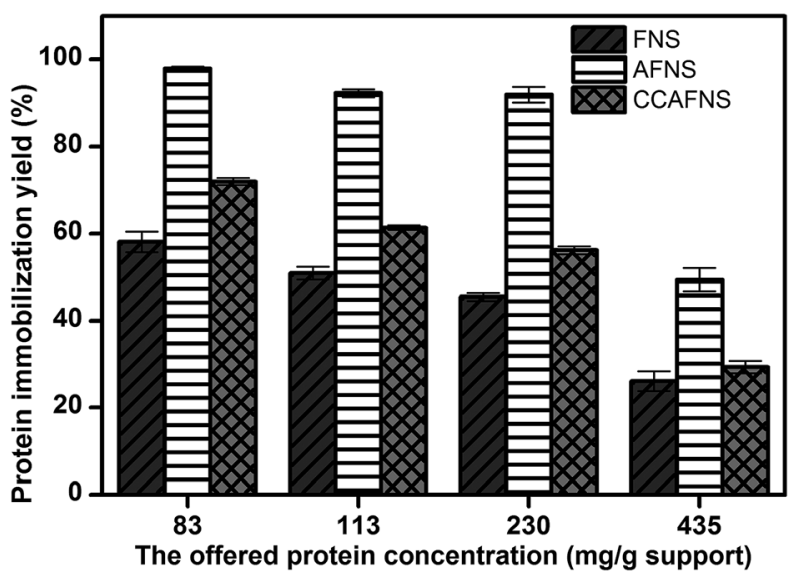

Fig. 2 The effect of the offered protein concentration on protein immobilization yield of $\beta$-galactosidase immobilized on FNS, AFNS and CCAFNS. Experimental conditions: $0.1 \mathrm{~mol} \mathrm{~L}^{-1}$ acetate buffer $\mathrm{pH}$ 4.5; immobilization time $3 \mathrm{~h}$; temperature $25^{\circ} \mathrm{C}$. of offered protein concentration on the expressed activity was investigated (Fig. 3). For all three supports, the expressed activity of immobilized $\beta$-galactosidase displayed the same course as protein loading, meaning that with increment of the offered protein concentration up to $230 \mathrm{mg} \mathrm{g}^{-1}$ support the expressed activity also increases. At higher offered protein concentration (435 $\mathrm{mg} \mathrm{g}^{-1}$ of support) decrease of activity of immobilized enzyme on AFNS for $20 \%$ was observed, while loss of activity of immobilized enzymes on FNS and CCAFNS was even $40 \%$.

This reduction of activity at the highest offered protein concentration can be explained by the fact that excessive protein loadings are likely to cause agglomeration of enzyme molecules attached onto the surface of supports. ${ }^{45}$ Also, the steric hindrance effect between adjacent groups of support and enzyme can restrain diffusion of substrate, thus leading to lower activity of immobilized enzyme, ${ }^{46}$ as was observed during immobilization of particular enzyme on ionic exchange resin Duolite A568. ${ }^{44}$ It needs to be emphasized that achieved expressed activity $\left(\sim 2100 \mathrm{IU} \mathrm{g}^{-1}\right)$ of enzyme immobilized on AFNS is approximately 70, 7 and 4 times higher than previously obtained in immobilization on Purolite, ${ }^{20}$ hierarchical mesomacroporous glyoxyl-silica and glyoxyl agarose, ${ }^{23}$ respectively. In case of nano-sized supports, it is even two orders of magnitude higher than on graphene based magnetic nanoparticles. ${ }^{2}$ All of these facts indicate great potential of nano-silica in A. oryzae $\beta$ galactosidase immobilization.

In summary, with respect to both, protein loading and expressed activity, it was shown that excessive increase of offered enzyme concentration is futile since each of examined nano-silica based supports exhibited the best results when the immobilization was carried out at the offered protein concentration of $230 \mathrm{mg} \mathrm{g}^{-1}$ support, therefore subsequent experimental series was performed in such conditions.

Obtained results (Fig. 3 and Table 1) indicate that AFNS, among analyzed nano-silica supports, provides by far the most appropriate chemistry for the immobilization of $\beta$-galactosidase

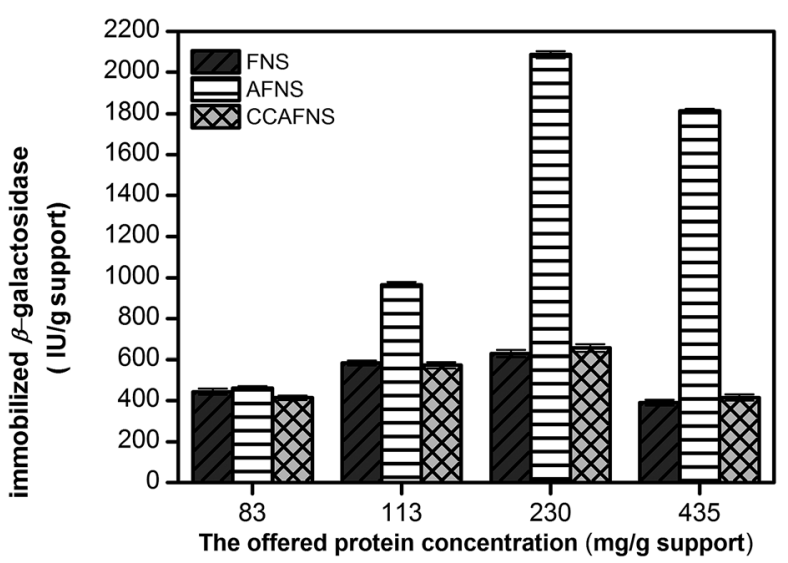

Fig. 3 The impact of the offered protein concentration on the expressed activity of $\beta$-galactosidase immobilized on FNS, AFNS and CCAFNS. Experimental conditions: $0.1 \mathrm{~mol} \mathrm{~L}^{-1}$ acetate buffer $\mathrm{pH}$ 4.5; immobilization time $3 \mathrm{~h}$; temperature $25^{\circ} \mathrm{C}$. 
Table 1 Comparison of $\beta$-galactosidase immobilization on FNS, AFNS and CCAFNS obtained in 0.1 mol L $\mathrm{L}^{-1}$ acetate buffer at $230 \mathrm{mg}$ protein per $\mathrm{g}$ of support during $3 \mathrm{~h}$

\begin{tabular}{|c|c|c|c|c|c|}
\hline Support & $\begin{array}{l}\text { Mass of bound enzyme } \\
\left(\mathrm{mg} \mathrm{g}^{-1} \text { support }\right)\end{array}$ & IYp (\%) & $\begin{array}{l}\text { Expressed activity of immobilized } \\
\text { enzyme (IU g }{ }^{-1} \text { support) }\end{array}$ & IYa (\%) & $\begin{array}{l}\text { Specific activity } \\
\text { (IU mg }{ }^{-1} \text { protein) }\end{array}$ \\
\hline FNS & 107 & 45 & 629 & 10 & 5 \\
\hline AFNS & 211 & 91 & 2087 & 52 & 9 \\
\hline CCAFNS & 129 & 56 & 658 & 14 & 5 \\
\hline
\end{tabular}

with respect to activity of immobilized enzyme. Presumably, the immobilization on AFNS occurs via electrostatic adsorption between amino groups on support and carboxylic groups in side chains of amino acids, while basic residues reduce immobilization due to repulsive forces. Since groups involved in these interactions are weak basis and acids, $\mathrm{pH}$ should have significant influence; hence it was analyzed in additional experiment with AFNS. Results (Table 2) clearly show that immobilization is by far the most efficient at pH 5 .

Significant impact of $\mathrm{pH}$ on immobilization can be explained by the fact that enzymes are more prone to interact with positively charged functional groups if they are negatively charged, which occurs at $\mathrm{pH}$ values above their $\mathrm{pI}$, which is around 4.6 for $\beta$-galactosidase from $A$. oryzae. ${ }^{44}$ However, overall enzyme charge is not the only factor that influences adsorption via ionic interactions, since distribution of charged residues on the surface of enzyme also governs the efficiency of immobilization by directing the orientation of adsorbed molecules. Since surface of the support is positively charged throughout examined $\mathrm{pH}$ range due to primary amino groups, it can be assumed that distribution of negatively charged residues and properties of residues in their vicinity cause large discrepancies in efficiency of immobilization at different $\mathrm{pH}$ values. The effect of $\mathrm{pH}$ on the efficiency of immobilization could be further explained by distribution of amino acid residues relevant for adsorption on the surface of $\beta$-galactosidase from A. oryzae (Fig. 4).

According to studies of $\mathrm{p} K$ values of ionizable groups in folded proteins average $\mathrm{p} K$ values of aspartic and glutamic residues are around 4 , but $\mathrm{p} K \mathrm{~s}$ of individual residues vary in very wide range from 1 up to 9 due to the effects of environment. ${ }^{47-50}$ The $\mathrm{pKs}$ of carboxyl groups increase in vicinity of hydrophobic environment usually encountered when groups are partially or completely buried in proteins, while presence of positively charged groups decrease the $\mathrm{p} K$ of carboxyl groups. ${ }^{47}$ If we apply these findings on our immobilization, it is plausible that carboxyl groups in region opposite to active site of $\beta$ -

Table 2 The influence of $\mathrm{pH}$ on efficiency of $\beta$-galactosidase immobilization on AFNS

\begin{tabular}{ll}
\hline $\begin{array}{ll}\text { Immobilization } \\
\text { buffer pH }\end{array}$ & $\begin{array}{l}\text { Expressed activity of immobilized } \\
\left.\beta \text {-galactosidase (IU g }{ }^{-1} \text { support }\right)\end{array}$ \\
\hline pH 4 & 1350 \\
pH 4.5 & 2087 \\
pH 5 & 2284 \\
pH 6 & 921 \\
pH 7 & 466
\end{tabular}
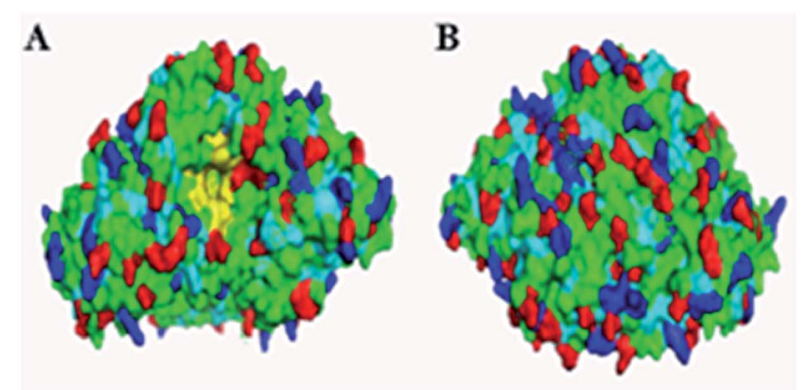

Fig. 4 Distribution of amino acids that have amino and carboxylic acid group on the surface of the $\beta$-galactosidase from $A$. oryzae. Residues with amino group are shown in dark blue, residues with carboxylic acid group in red, hydrophobic regions in light blue and the active site in yellow. Front view on active site. (A) $180^{\circ}$ rotation of the front view in $x-y$ plane. (B) The 3D structure was obtained using Pymol vs. 0.99 and data obtained from Protein Data Bank (PDB). PDB code for $\beta$-galactosidase from $A$. oryzae is 4IUG.

galactosidase from A. oryzae, which are exposed on the surface and surrounded with numerous amino groups (Fig. 4A), have $\mathrm{p} K$ values even less than 4 meaning they are charged throughout examined $\mathrm{pH}$ range and attractive forces between support and enzyme are imminent if adsorption occurs via this region. On the other hand, in vicinity of active site carboxyl groups are more abundant than amino groups and their environment is more hydrophobic, which should increase their $\mathrm{p} K$ values above average value. Therefore, it is plausible that these groups become charged only at $\mathrm{pH}$ values above 5 , which directs adsorption towards this region because it is favorable due to the lack of repulsive forces caused by amino groups. Since these groups are in vicinity of active site, steric obstacles for approach of substrate to active site lead to drastically lower activity of immobilized enzyme.

Summing previously imposed statements, it can be assumed that enzyme molecules are dominantly adsorbed on a positively charged surface of AFNS via electrostatic attractions with negatively charged carboxyl groups exposed in the region opposite to active site. The established interactions orients enzyme in such way that allows easy access of the substrate to the active site. Opposite to AFNS, negatively charged silanol groups of FNS form electrostatic attractions with positively charged amino groups present in the vicinity of active cite. In this case adsorption occurs through groups in neighborhood of active site, so it leads to steric obstacles for the approach of substrate to the active site, resulting with the drastically lower activity of immobilized enzyme. Nevertheless, it should be 
emphasized that between both supports and enzyme molecules, beside electrostatic interactions, could be also formed hydrophobic interaction, week van der Waals forces and hydrogen bonds. Their contribution is significant through stabilization of occupied orientation of adsorbed molecules via dominant electrostatic interactions. ${ }^{\mathbf{5 1}}$

The immobilization of $\beta$-galactosidase on CCAFNS surface should predominantly occur between the amino groups located on $\beta$-galactosidase surface and chlorine atoms of the attached cyanuric chloride on CCAFNS surface. It seems that formed covalent bonds turned to be disadvantageous since active sites have become blocked and inaccessible for substrate. As result, activity immobilization yield and specific activity of $\beta$-galactosidase immobilized on CCAFNS was significantly lower than for enzyme adsorbed on AFNS (Table 1).

From all presented results, it can be concluded that immobilization of $\beta$-galactosidase is more favorable via carboxyl residues than via amino acid residues present on enzyme surface which is in agreement with our previously reported study. ${ }^{20}$

\section{Thermal stability study}

In order to investigate applicability of the immobilized enzymes on the industrial scale, the thermal stability of $\beta$-galactosidase immobilized on FNS, AFNS and CCAFNS was assessed at $60{ }^{\circ} \mathrm{C}$. The obtained results (Fig. 5) clearly indicate that the highest stability is achieved with enzyme immobilized on AFNS. $\beta$ Galactosidase immobilized on AFNS and CCAFNS retained 72\% and $35 \%$ of the initial activity after $12 \mathrm{~h}$ of incubation at $60{ }^{\circ} \mathrm{C}$, respectively. Thermal stability of $\beta$-galactosidase immobilized on FNS did not differ significantly with regard to thermal stability of free enzyme. The half-life of the immobilized enzymes on AFNS and CCAFNS were $24 \mathrm{~h}$ and $10 \mathrm{~h}$, respectively, while half-life of free $\beta$-galactosidase was only $2.5 \mathrm{~h}$. Although, it was expected that covalently bound enzyme on CCAFNS was more stable than adsorbed on AFNS, the lower stability of the

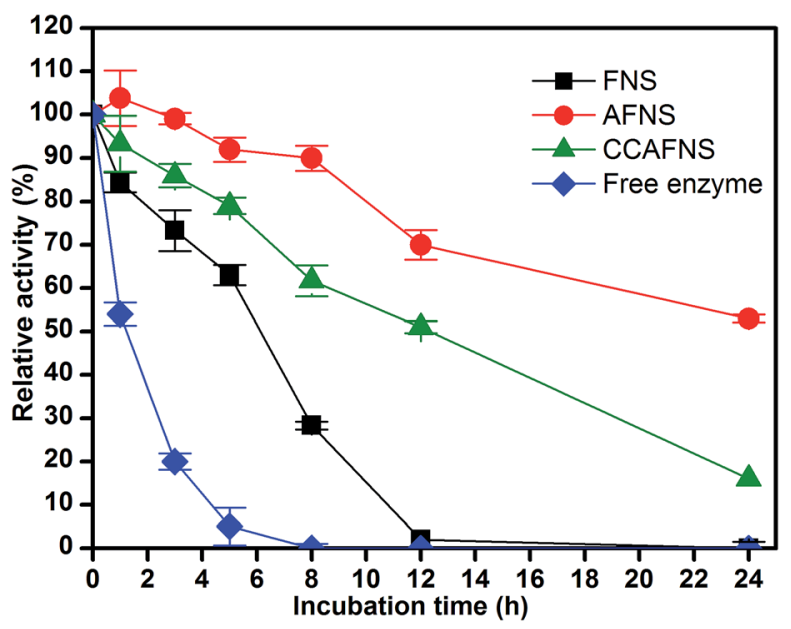

Fig. 5 Thermal stability of free $\beta$-galactosidase and $\beta$-galactosidase immobilized on FNS, AFNS and CCAFNS at $60^{\circ} \mathrm{C}$. Immobilization was performed at the offered protein concentration of $230 \mathrm{mg} \mathrm{g}^{-1}$ support during $3 \mathrm{~h}$. immobilized $\beta$-galactosidase on CCAFNS suggests that low number of interactions between lysine groups and chloride groups of CCAFNS was established. Presence of lysine groups as well as the number of formed covalent bonds plays the critical role in stability of immobilized $\beta$-galactosidase as evidenced by the case of stability of covalently immobilized $\beta$-galactosidase on glyoxyl-agarose and chitosan-coated magnetic nanoparticles with tris(hydroxymethyl)phosphine. ${ }^{28,52}$

So, results of thermal stability study confirm that immobilization of $\beta$-galactosidase on AFNS provides advantage of improved rigidity and resistance to unfolding during heat treatment in addition to previously observed increased activity.

\section{Production of galacto-oligosaccharides}

Since AFNS is the most prospective among obtained immobilized derivatives, it was further evaluated in bio-conversion of lactose into galacto-oligosaccharides (GOS) (Scheme 2). During enzymatic lactose conversion, two competing reactions, hydrolysis and transgalactosylation, take place as presented in Scheme 2 . Firstly, $\beta$-galactosidase attacks $\beta$ - $(1 \rightarrow 4)$ glycosidic linkage in lactose molecule and as result enzyme-galactosyl complex is formed. The hydrolysis will happen if water acts as galactosyl acceptor and as end products glucose and galactose will be produced. Meanwhile, GOS will be made through transgalactosylation reaction which means that enzyme instead of transferring the galactosyl unit to the hydroxyl group of water transfers it to another lactose molecule. Generally, shifting towards transgalactosylation reaction occurs in the concentrated lactose solutions (above $200 \mathrm{~g} \mathrm{~L}^{-1}$ ); because they contain more sugar molecules that can compete with water molecules leading to increase in production of GOS. ${ }^{4}$ The GOS synthesis was performed at initial lactose concentration of $400 \mathrm{~g} \mathrm{~L}^{-1}, \mathrm{pH}$ 4.5 and $50{ }^{\circ} \mathrm{C}$, since these reaction conditions are determined as optimal in our previously reported study. ${ }^{20}$

In Fig. 6 GOS syntheses using AFNS-immobilized $\beta$-galactosidase and free enzyme are compared. For adequate estimation of $\beta$-galactosidase affinity towards transgalactosylation, the GOS synthesis was carried out with the amounts of free $\beta$-galactosidase that provide equal initial hydrolytic activity $\left(10 \mathrm{IU} \mathrm{mL}^{-1}\right)$ of free $\beta$-galactosidase and immobilized on AFNS. Immobilized enzyme demonstrated rapid increase in production of total mass of GOS during first hour, resulting in maximum total GOS of $91 \mathrm{~g} \mathrm{~L}^{-1}$ (Fig. 6A). Apparently, it took three hours for free enzyme to produce the same amount of total GOS meaning that the AFNS immobilized preparation appears to have better catalytic capability for synthesizing GOS than free enzyme. The concentration of total GOS produced by immobilized and free $\beta$ galactosidase was plotted against the percentage of lactose conversion (light grey curves at Fig. 6A and B). As observed, total GOS production decreased after a certain degree of lactose conversion. This is due to the fact that simultaneously with synthetic reaction hydrolysis of lactose (formation of glucose and galactose) and GOS occurs, hence for each reaction system equilibrium point in which hydrolysis prevails GOS synthesis must be determined. The maximum amount of total GOS for the immobilized enzyme was achieved at lactose conversion of 


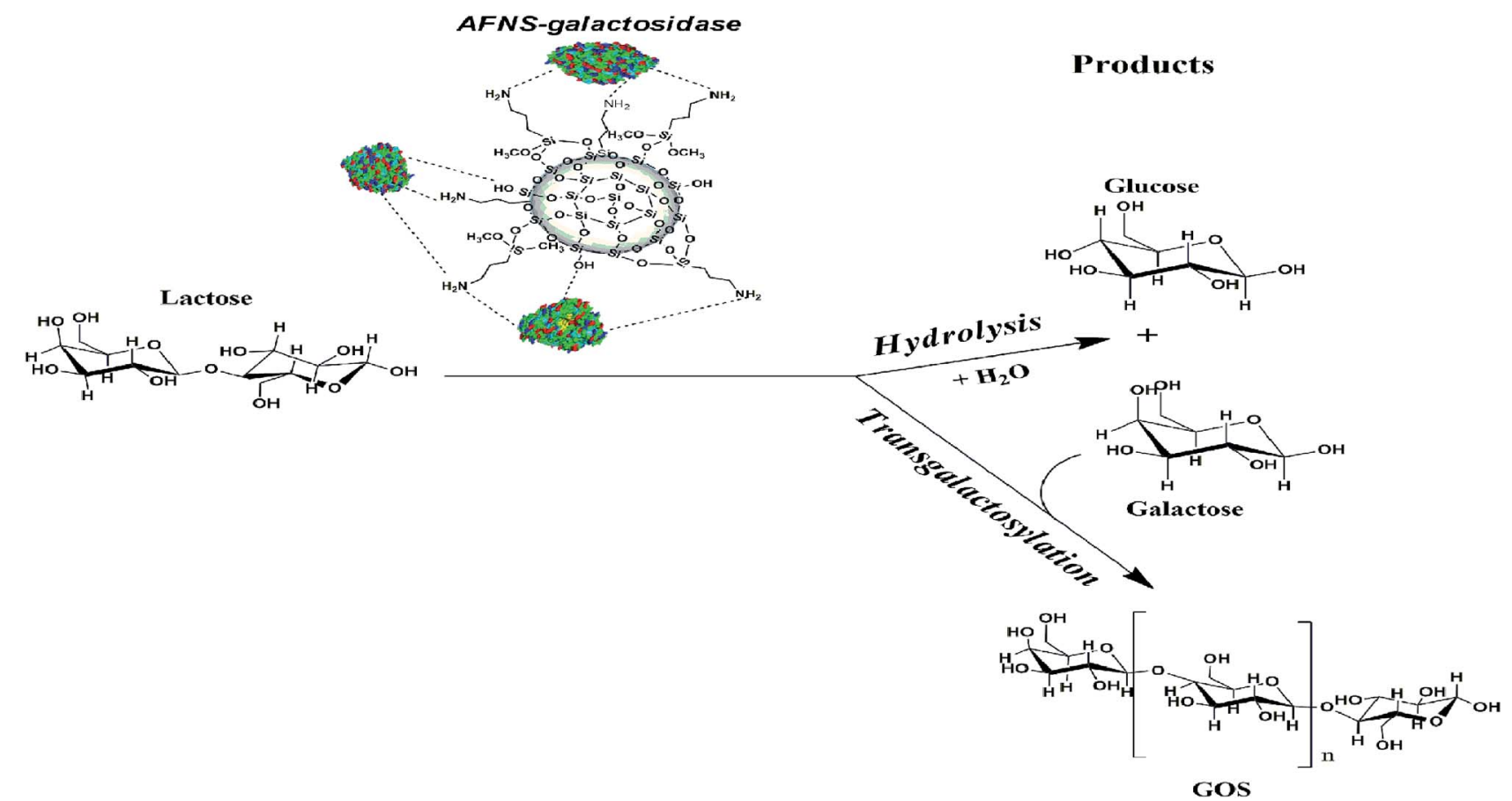

Scheme 2 Schematic presentation of GOS synthesis catalysed by immobilized $\beta$-galactosidase.
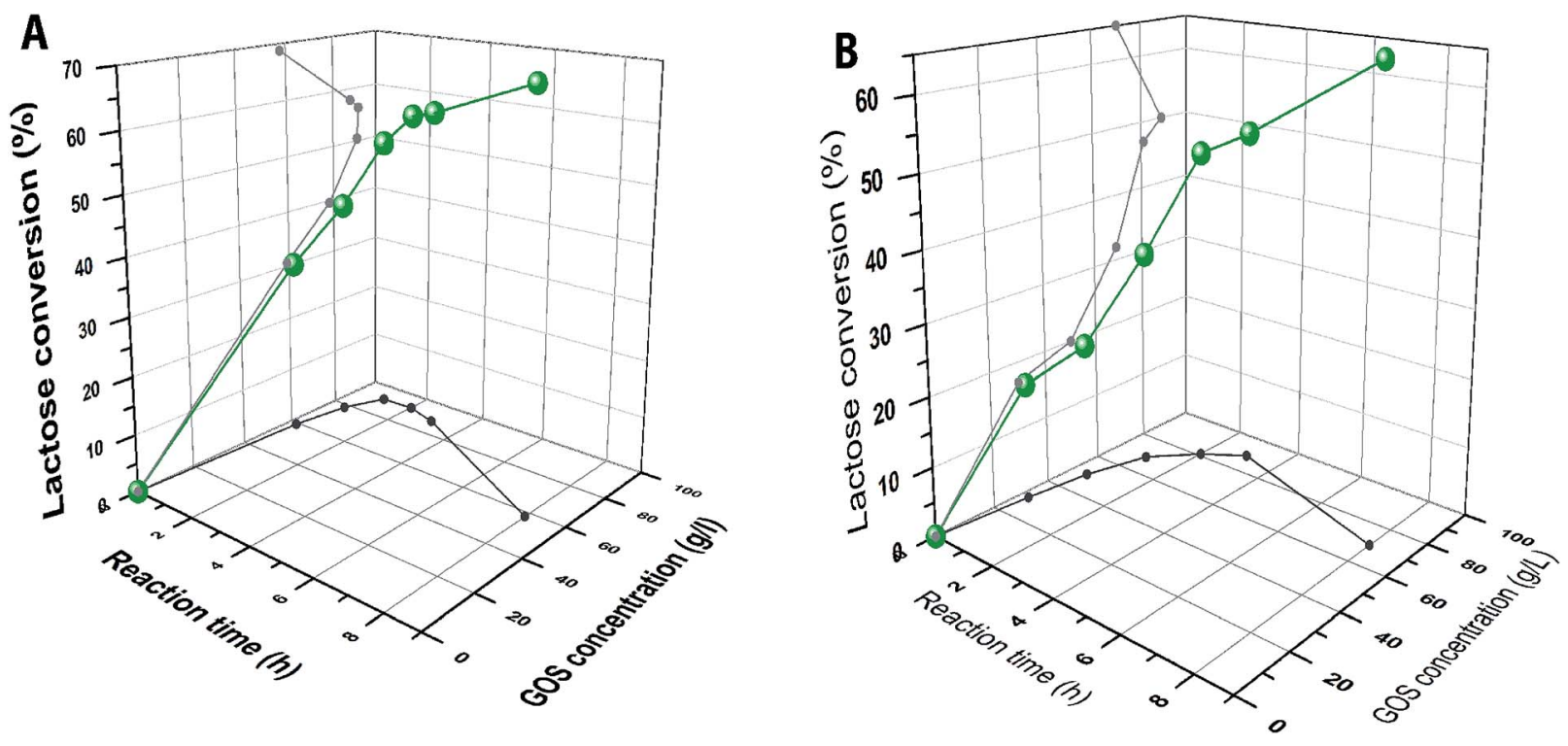

Fig. 6 Time course of total GOS formation (dark grey curve) and impact of lactose conversion on concentration of total GOS (light grey curve) using $\beta$-galactosidase immobilized on AFNS (A) and free $\beta$-galactosidase (B).

$56 \%$. For the free enzyme, the corresponding value of $90.9 \mathrm{~g} \mathrm{~L}^{-1}$ was obtained for about $50 \%$ lactose conversion. Considering the very small size $(7 \mathrm{~nm})$ and nonporous structure of the AFNS particles, presented results confirm that enzyme immobilization on AFNS does not impose any mass transfer limitations on GOS formation from lactose. Also, use of immobilized enzyme is interesting since it allows higher lactose conversion degrees, which is beneficial for GOS downstream processing. The concentration of reaction species (glucose, galactose, lactose,
GOS 3 and GOS 4) of lactose bioconversion as a function of reaction time is depicted at Fig. 7 .

From presented results, it can be observed that hydrolysis and transgalactosylation occur simultaneously during first hour with the lactose conversion rate of $200 \mathrm{~g} \mathrm{~L}^{-1} \mathrm{~h}^{-1}$. Yet it can be noted that transgalactosylation dominates the lactose bioconversion, since the AFNS immobilized preparation have produced $76 \mathrm{~g} \mathrm{~L}^{-1}$ of glucose, $64.8 \mathrm{~g} \mathrm{~L}^{-1}$ of GOS 3 and $22.73 \mathrm{~g}$ 


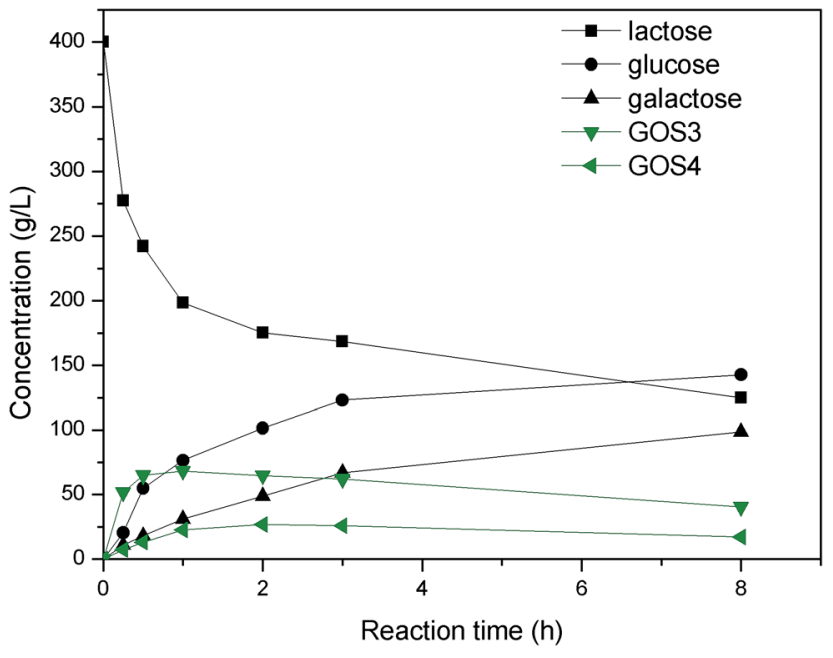

Fig. 7 Reaction mixture concentration changes in the product stream at different reaction time for $\beta$-galactosidase immobilized on AFNS. Reaction conditions: temperature $50{ }^{\circ} \mathrm{C}$; initial lactose concentration $400 \mathrm{~g} \mathrm{~L}^{-1} ; 100 \mathrm{mg}$ of immobilized $\beta$-galactosidase.

$\mathrm{L}^{-1}$ of GOS 4 implying that overall GOS production was 1.3times higher than glucose production.

The prominence of transgalactosylation is also confirmed by steeper increase of glucose in comparison with galactose, which indicates that galactose is being incorporated in GOS in significant extent. After three hours, the slopes of these curves become similar, while concentration of GOS 3 and GOS 4 exhibited slight decrease suggesting that hydrolysis was slowly becoming predominant.

Considering the GOS productivity of the immobilized preparation acquired $\left(90 \mathrm{~g} \mathrm{~L}^{-1} \mathrm{~h}^{-1}\right)$, our result is by far larger than those previously obtained in other studies. For instance, productivity of $\beta$-galactosidase immobilized on genipin crosslinked chitosan particles was found to be $38.66 \mathrm{~g} \mathrm{~L}^{-1} \mathrm{~h}^{-1}$ under same conditions as in this study..$^{53}$ Also, $\beta$-galactosidase immobilized on AFNS, exhibited 15 -folds higher productivity ( $\mathrm{g}$ of synthetized GOS per $\mathrm{g}$ of support per $\mathrm{h}$ ) than same amount of immobilized $\beta$-galactosidase on Purolite A109. ${ }^{20}$

\section{Operational stability study}

One of the advantages associated with the industrial application of immobilized enzymes is possibility for their multiple usages which increase overall cost-effectiveness of process. For that purpose, the reuse potential of AFNS immobilized $\beta$-galactosidase was examined in five reaction cycles. The obtained results showed that this immobilized preparation could be reused in GOS synthesis, since after fifth cycle the immobilized enzyme retained $50 \%$ of initial activity. Additionally, during reuse leaching of enzyme from support surface was not detected by protein assay.

The absence of mass transfer limitation on the immobilized enzyme, high GOS productivity coupled with the increased thermal stability and operational stability impose conclusion that $\beta$-galactosidase immobilized on AFNS has prospects in application in transgalactosylation processes.

\section{Conclusions}

The immobilization of $A$. oryzae $\beta$-galactosidase onto unmodified, amino- and CC-functionalized silica nanoparticles proved to be justified due to achieved high enzyme loadings and immobilized activities. Among analyzed nano-silica supports enzyme exhibited the highest affinity towards one with amino groups, which is in accordance with our previous findings with the same enzyme and support with different scaffold, but identical functional group. Hence, in this manuscript the attempt to elucidate mechanism of immobilization, based on available enzyme conformation and investigated effect of $\mathrm{pH}$ on immobilization, was presented. Obtained immobilized $\beta$ galactosidase activity per gram of support is hugely increased in comparison with previously reported values with supports that were not nano-materials. Finally, AFNS-immobilized enzyme has shown high thermal stability and activity in transgalactosylation, which recommends it for use in synthesis of valuable bioactive galactosides.

\section{Acknowledgements}

Authors are grateful to Ministry of Education, Science and Technological Development of Republic of Serbia for the financial support within projects III 46010, 172013 and III 45019.

\section{References}

1 A. Nath, S. Mondal, S. Chakraborty, C. Bhattacharjee and R. Chowdhury, Asia-Pac. J. Chem. Eng., 2014, 9, 330-348.

2 M. Khan, Q. Husain and A. H. Naqvi, RSC Adv., 2016, 6, 53493-53503.

3 A. Gosling, G. W. Stevens, A. R. Barber, S. E. Kentish and S. L. Gras, Food Chem., 2010, 121, 307-318.

4 D. P. Torres, M. Gonçalves, J. A. Teixeira and L. R. Rodrigues, Compr. Rev. Food Sci. Food Saf., 2010, 9, 438-454.

5 Y. Zhou, J. Chu, J. Zhang, K. Liu and B. He, RSC Adv., 2016, 6, 64841-64846.

6 A. Nath, B. Verasztó, S. Basak, A. Koris, Z. Kovács and G. Vatai, Food Bioprocess Technol., 2015, 9, 16-48.

7 M. Carević, D. Veličković, M. Stojanović, N. Milosavić, H. Rogniaux, D. Ropartz and D. Bezbradica, Process Biochem., 2015, 50, 782-788.

8 Y. Qiao, Y. Huang, F. Feng and Z.-G. Chen, Process Biochem., 2016, 51, 675-680.

9 B. Zeuner, C. Nyffenegger, J. D. Mikkelsen and A. S. Meyer, New Biotechnol., 2016, 33, 355-360.

10 A. Aires-Trapote, A. Tamayo, J. Rubio, A. Rumbero and M. J. Hernáiz, RSC Adv., 2015, 5, 40375-40383.

11 C. Vera, C. Guerrero and A. Illanes, Carbohydr. Res., 2011, 346, 745-752.

12 M. Carević, D. Bezbradica, K. Banjanac, A. Milivojević, M. Fanuel, H. Rogniaux, D. Ropartz and D. Veličković, $J$. Agric. Food Chem., 2016, 64, 3609-3615.

13 I. González-Delgado, M.-J. López-Muñoz, G. Morales and Y. Segura, Int. Dairy J., 2016, 61, 211-219. 
14 P. Torres and F. Batista-Viera, J. Mol. Catal. B: Enzym., 2012, 83, 57-64.

15 E. Van Leusen, E. Torringa, P. Groenink, P. Kortleve, R. Geene, M. Schoterman and B. Klarenbeek, in Food Oligosaccharides: Production, Analysis and Bioactivity, 2014, pp. 470-491.

16 P. Sen, A. Nath, C. Bhattacharjee, R. Chowdhury and P. Bhattacharya, Biochem. Eng. J., 2014, 90, 59-72.

17 P. Urrutia, C. Bernal, L. Wilson and A. Illanes, J. Agric. Food Chem., 2014, 62, 10126-10135.

18 B. N. Estevinho, A. M. Damas, P. Martins and F. Rocha, Food Res. Int., 2014, 64, 134-140.

19 A. Warmerdam, E. Benjamins, T. F. de Leeuw, T. A. Broekhuis, R. M. Boom and A. E. M. Janssen, Food Bioprod. Process., 2014, 92, 383-392.

20 M. Carević, M. Ćorović, M. Mihailović, K. Banjanac, A. Milisavljević, D. Veličković and D. Bezbradica, Int. Dairy J., 2016, 54, 50-57.

21 J. Fischer, C. Z. Guidini, L. N. S. Santana, M. M. de Resende, V. L. Cardoso and E. J. Ribeiro, J. Mol. Catal. B: Enzym., 2013, 85-86, 178-186.

22 E. Biró, D. Budugan, A. Todea, F. Péter, S. Klébert and T. Feczkó, J. Mol. Catal. B: Enzym., 2016, 123, 81-90.

23 C. Bernal, P. Urrutia, A. Illanes and L. Wilson, New Biotechnol., 2013, 30, 500-506.

24 Y. Satyawali, S. V. Roy, A. Roevens, V. Meynen, S. Mullens, P. Jochems, W. Doyen, L. Cauwenberghs and W. Dejonghe, RSC Adv. , 2013, 3, 24054-24062.

25 E. Selvarajan, V. Mohanasrinivasan, C. Subathra Devi and C. George Priya Doss, Bioprocess Biosyst. Eng., 2016, 38, 1655-1669.

26 S. A. Ansari and Q. Husain, Biotechnol. Adv., 2012, 30, 512523.

27 M. Misson, H. Zhang and B. Jin, J. R. Soc., Interface, 2015, 12, 20140891-20140919.

28 S.-C. Chen and K.-J. Duan, Int. J. Mol. Sci., 2015, 16, 1249912512.

29 M. Hartmann and X. Kostrov, Chem. Soc. Rev., 2013, 42, 6277-6289.

30 C. Bernal, L. Sierra and M. Mesa, Eng. Life Sci., 2014, 14, 8594.

31 M. Misson, X. Du, B. Jin and H. Zhang, Enzyme Microb. Technol., 2016, 84, 68-77.

32 K. Banjanac, M. Mihailović, N. Prlainović, M. Stojanović, M. Carević, A. Marinković and D. Bezbradica, J. Chem. Technol. Biotechnol., 2016, 91, 439-448.
33 K. Banjanac, M. Mihailović, N. Prlainović, M. Ćorović, M. Carević, A. Marinković and D. Bezbradica, J. Chem. Technol. Biotechnol., 2016, 91, 2654-2663.

34 A. Bitar, N. M. Ahmad, H. Fessi and A. Elaissari, Drug Discovery Today, 2012, 17, 1147-1154.

35 P. Tallury, K. Payton and S. Santra, Nanomedicine, 2008, 3, 579-592.

36 M. M. Bradford, Anal. Biochem., 1976, 72, 248-254.

37 J. C. Cruz, P. H. Pfromm, J. M. Tomich and M. E. Rezac, Colloids Surf., B, 2010, 81, 1-10.

38 J. C. Cruz, K. Würges, M. Kramer, P. H. Pfromm, M. E. Rezac and P. Czermak, in Nanoscale Biocatalysis: Methods and Protocols, ed. P. Wang, Humana Press, Totowa, NJ, 2011, pp. 147-160.

39 I. F. Mironyuk, V. M. Gun'ko, V. V. Turov, V. I. Zarko, R. Leboda and J. Skubiszewska-Zięba, Colloids Surf., A, 2001, 180, 87-101.

40 J. Kim, P. Seidler, C. Fill and L. S. Wan, Surf. Sci., 2008, 602, 3323-3330.

41 A. Razi and S. Meryam, Biochem. Anal. Biochem., 2015, 4, 178.

42 C. Pan, B. Hu, W. Li, Y. Sun, H. Ye and X. Zeng, J. Mol. Catal. B: Enzym., 2009, 61, 208-215.

43 Q. Husain, S. A. Ansari, F. Alam and A. Azam, Int. J. Biol. Macromol., 2011, 49, 37-43.

44 C. Z. Guidini, J. Fischer, L. N. S. Santana, V. L. Cardoso and E. J. Ribeiro, Biochem. Eng. J., 2010, 52, 137-143.

45 F. Wang, C. Guo, H.-Z. Liu and C.-Z. Liu, J. Chem. Technol. Biotechnol., 2008, 83, 97-104.

46 Y. Liu, Z. Zeng, G. Zeng, L. Tang, Y. Pang, Z. Li, C. Liu, X. Lei, M. Wu, P. Ren, Z. Liu, M. Chen and G. Xie, Bioresour. Technol., 2012, 115, 21-26.

47 G. R. Grimsley, J. M. Scholtz and C. N. Pace, Protein Sci., 2009, 18, 247-251.

48 C. N. Pace, G. R. Grimsley and J. M. Scholtz, J. Biol. Chem., 2009, 284, 13285-13289.

49 H. Li, A. D. Robertson and J. H. Jensen, Proteins: Struct., Funct., Bioinf., 2005, 61, 704-721.

50 S. Lindman, M. C. Bauer, M. Lund, C. Diehl, F. A. A. Mulder, M. Akke and S. Linse, Biophys. J., 2010, 99, 3365-3373.

51 W. Norde, F. MacRitchie, G. Nowicka and J. Lyklema, J. Colloid Interface Sci., 1986, 112, 447-456.

52 L. M. Huerta, C. Vera, C. Guerrero, L. Wilson and A. Illanes, Process Biochem., 2011, 46, 245-252.

53 M. P. Klein, C. R. Hackenhaar, A. S. G. Lorenzoni, R. C. Rodrigues, T. M. H. Costa, J. L. Ninow and P. F. Hertz, Carbohydr. Polym., 2016, 137, 184-190. 